\title{
EFFECT OF INTERCROPPING WHITE CABBAGE \\ WITH FRENCH MARIGOLD (TAGETES PATULA NANA) \\ AND POT MARIGOLD (CALENDULA OFFICINALIS) \\ ON DIAMONDBACK MOTH (PLUTELLA XYLOSTELLA L.) POPULATION DENSITY AND IT'S PARASITOID COMPLEX
}

\author{
Beata JANKOWSKA \\ University of Agriculture in Kraków \\ Faculty of Horticulture, Department of Plant Protection \\ 29 Listopada 54, 31-425 Kraków, Poland \\ Received: May 12, 2010; Accepted: July 27, 2010
}

\begin{abstract}
Summary
The impact of intercropping white cabbage ('Bently $\mathrm{F}_{1}$ ') with French Marigold Tagetes patula nana 'Kolombina' and Pot Marigold Calendula officinalis 'Promyk' on the occurrence of diamondback moth (DBM) (Plutella xylostella L.) and its parasitoid complex was estimated in years 2003-2005. The number of DBM larvae and pupae was significantly lower on plots where cabbage was intercropped compared with the control variant (homogenous crop). The combination with Pot Marigold turned out to be the best in this respect. The DBM larvae parasitization level varied from year to year and its percentage oscillated from 65 to $88 \%$. Eight beneficial insect species belonging to families: Ichneumonidae (4 species), Braconidae (2 species), Pteromalidae (1 species) and Eulophidae (1 species) emerged from collected DBM pupae. Diadegma fenestralis Holmgr. was the most abundant species among all Plutella parasitoids every year of observations as it constitued $65 \%$ of all of the reared wasps. No significant differences were determined between the level of parasitization in relation to the type of cultivation.
\end{abstract}

key words: Plutella xylostella, cabbage, intercropping, parasitoids

\section{INTRODUCTION}

The diamondback moth (DBM), Plutella xylostella (L.) (Lepidoptera: Plutellidae), remains one of the most damaging insect pests of brassica plants (Brassica sp.) worldwide. It is particularly dangerous to vegetables belonging to Brassicaceae family in Poland (Jankowska 2005, 2006) and have the potential to severely reduce the marketable yield or to completely destroy the crop. Overuse of broadspectrum insecticides for diamondback moth control is a serious problem and has obscured the contribu- 
of indigenous parasitoids. The absence of effective natural enemies, especially parasitoids is belived to be a major cause of the diamondback moth's pest status. Naturally occurring parasites are important factors regulating pest population densities (Łagowska 1981, Wiech \& Jankowska 1999, Jankowska \& Wiech 2006). The biodiversification of the cultivated landscape has been a research trend in many countries worldwide. Moreover there is an increased realization over the world that development of biological control including preservation or augmentation of natural enemies is the base of management programmes (Talekar \& Shelton 1993, Biever et al. 1994). Diversity of plants in agrocenosis may be an important factor that influences the presence of pests as well as their natural enemies. Intercropping is one of the ways to diversify the species populations in the field. The aim of this work was to determine the impact of intercropping white cabbage with Pot Marigold Calendula officinalis L. and French Marigold Tagetes patula nana of the presence of diamondback moth and its parasitoid complex.

\section{MATERIAL AND METHODS}

Observations on the occurrence of $P$. xylostella and its parasitoids were carried out in the Plant Protection Experimental Station in Mydlniki near Krakow, on brown soil developed on loess in 2003-2005. The experiment was designed as a randomized block, in three replications on $10.8 \mathrm{~m}^{2}$ plots. The combinations of the experiment included three objects: homogenous crop white cabbage crop
'Bently $\mathrm{F}_{1}$ ', cabbage intercropped with Tagetes patula nana 'Kolombina' and cabbage intercropped with Calendula officinalis 'Promyk'. Tagetes and $\mathrm{Ca}$ lendula were sown by hand on 22 April in 2003-2004, and 24 April in 2005. Cabbage was transplanted in spacing of $67.5 \times 40 \mathrm{~cm}$ between flower rows on 28 May in 2003-2004, and 3 June in 2005. On experimental plots no chemical treatments were applied and weeds were removed mechanically. Ten plants from each plot were selected and marked for inspections made on a weekly basis during which both diamondback moth caterpillars and pupae were counted. The collected pupae of the diamondback moth were kept separately in glass vials at the laboratory until either parasitoid or moth emerged. Results were statistically analysed using analysis of variance. The significance of differences between particular combinations was counted using Duncan test at the 5\% level.

\section{RESULTS AND DISCUSSION}

The diamondback moth was observed each year of the experiment and occurred in all combinations. The first instar larvae were leaf miners, but later instars fed on the leaf surface. Caterpillars did not feed on veins and the sign of their presence were either windows or holes in leaves. Feeding caterpillars were observed both on the upper and lower leaf surface. The biggest DBM infestation was observed in July (Fig.1). Also in the previous research Jankowska (2005) noted the biggest infestation of different cabbage vegetables by DBM larvae at the same time. The occurrence period of caterpillars was 
similar on all combinations, but statistically significant differences were found between infestation in accordance to the type of cultivation. On plots where cabbage was intercropped the number of DBM larvae and pupae was significantly lower compared with control variant (homogenous crop) (Table 1). The combination with Pot Marigold turned out to be the best in this respect. Vegetational diversity in the form of intercropping can result in reduced pest densities and increases the resistance of the environment (Wiech \& Kałmuk 2005, Jankowska et al. 2009). Andow (1991) analysed
209 studies involving 287 pest species. Compared with monocultures, the population of pest insects was lower in $52 \%$ of the studies (149 species). Meny studies reported lower abundance of $P$. xylostella in intercropping system with labiate herbs (Dover 1986), clover and french bean (Wiech \& Wnuk 1991), subterranean clover (Finch \& Kienegger 1997), stravbery clover (Theunissen \& Schelling 1996), white clover (Dover 1986, Wiech 1993), red clover (Åsman et al. 2001), tomatoes, garlic, dill, or clover (Buranday \& Raros 1975, Dover 1986).

Table 1. Occurrence of the diamondback moth (Plutella xylostella L.) larvae and pupae on the cabbage according to the type of cultivation (2003-2005)

\begin{tabular}{lccc}
\hline \multirow{2}{*}{\multicolumn{1}{c}{ Type of cultivation }} & \multicolumn{3}{c}{ Mean number larvae and pupae/30 plants } \\
\cline { 2 - 4 } & 2003 & 2004 & 2005 \\
\hline Cabbage (homogenous crop) & $13 \mathrm{~b}$ & $4.8 \mathrm{~b}$ & $5.3 \mathrm{~b}$ \\
Cabbage with Tagetes patula & $9.3 \mathrm{~b}$ & $1.0 \mathrm{a}$ & $0.8 \mathrm{a}$ \\
Cabbage with Calendula officinalis & $3.5 \mathrm{a}$ & $0.2 \mathrm{a}$ & $0.2 \mathrm{a}$ \\
\hline
\end{tabular}

Values followed by the same letter do not differ significantly at 5\% level

Phytophagous insects locate plants for oviposition on the basis of scent and visual stimuli. Characteristic plant odours (volatile chemicals) are credited with the major role of guiding phytophagous insects to their host plants. Biologically active compounds called glucosinolates are feeding and oviposition stimulants for such a crucifer specialist. According to many authors (Gupta \& Thorsteinson 1960, Srinivisan \& Moorthy 1991, Pawar \& Lawande 1995, Mitchel et al. 1997, Pivnick et al. 1990), Plutella xylostella is stimulated to oviposition on cabbage leaves by the secondary plant compound - allyl isothiocyanate. The proximity of plants which are not a host may mask the scent of host plant which hampers its finding (Perrin \& Philips 1978).

During 2003-2005 315 pupae of DBM were collected, but only 98 moths $(31 \%)$ were recovered from the cocoons. The most important factor decreasing the number of DBM was parasitization $(69 \%)$. The highest numbers of parasitoids were recorded in 2003 (Table 2, 3) when DBM was the most abundant. Result of rearing pupae of this pest are presented in Table 2. Total parasitization of DBM by all the parasitoids varied between the years and oscillated from 65 to $88 \%$ in the three years (Table 2). The dynamics of parasitizing was similar 
irrespective of the way of cropping (Fig. 2). High rates of parasitism were recorded throughout the whole period of infestation by the DBM (Fig. 2).
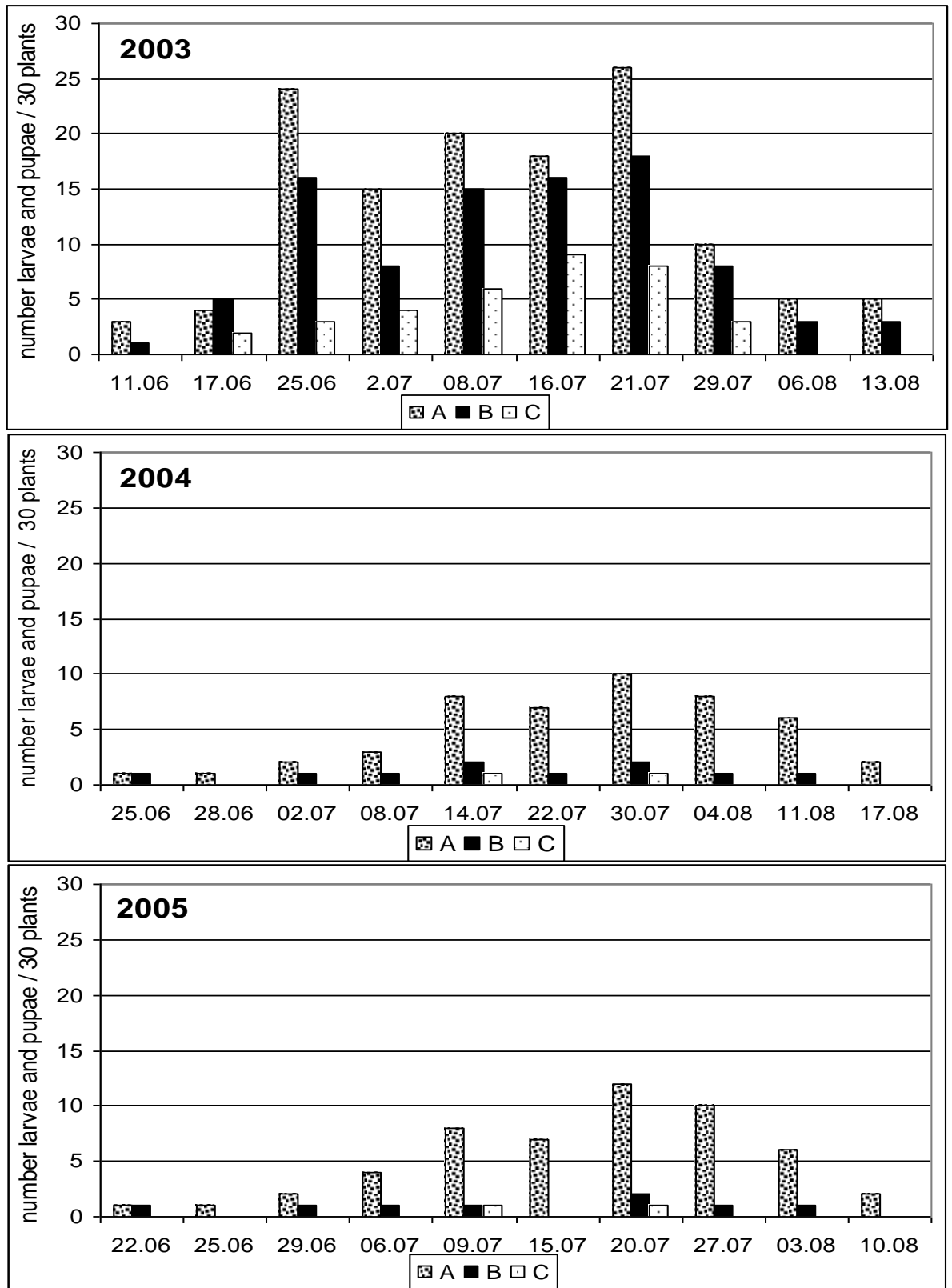

A - cabbage in homogenous crop

B - cabbage intercropped with French Marigold (Tagetes patula nana)

C - cabbage intercropped with Pot Marigold (Calendula officinalis)

Fig. 1. Comparison of diamondback moth (Plutella xylostella L.) dynamics in relation to the cultivation method (2003-2005) 

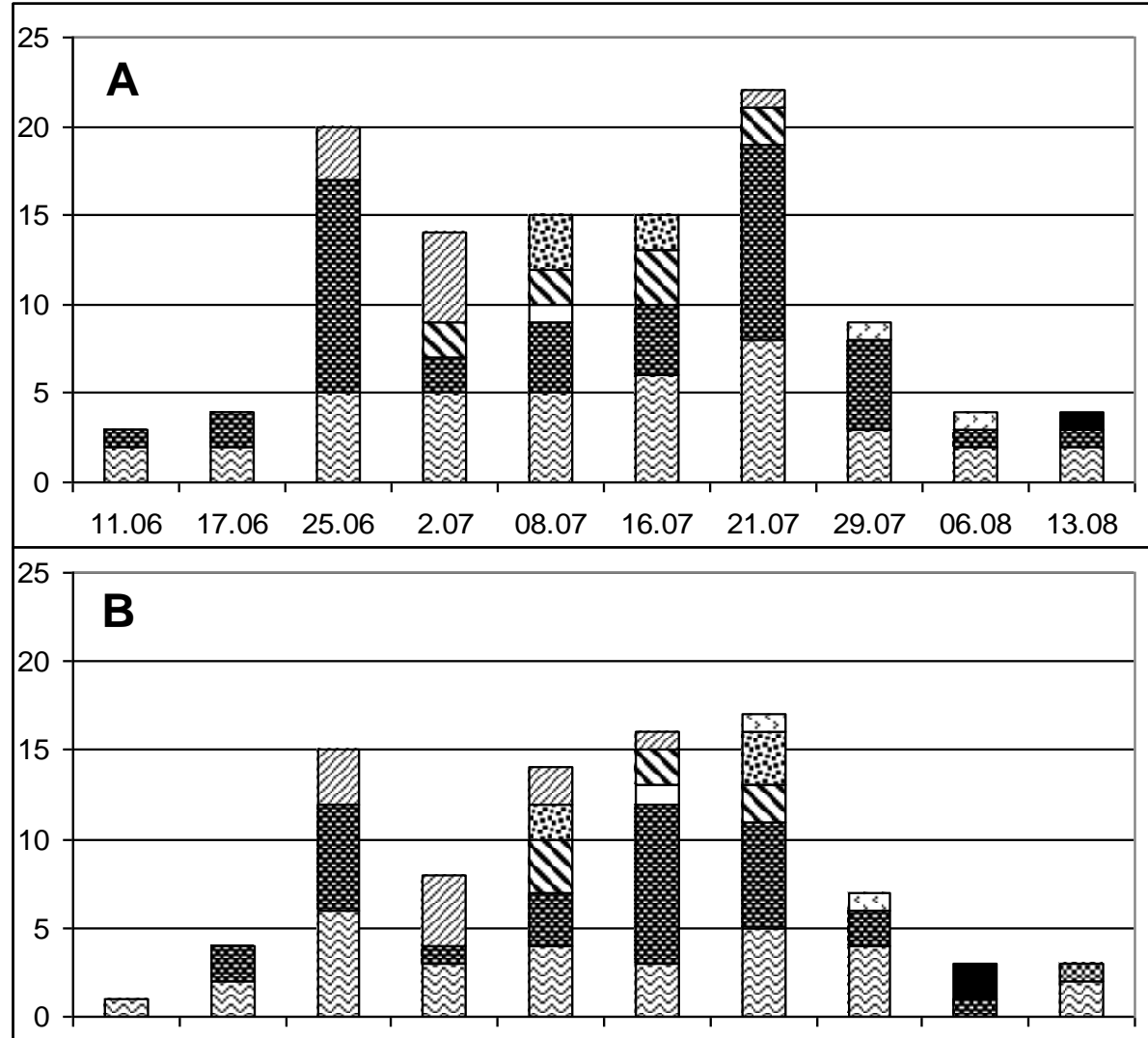

$\begin{array}{llllllllll}11.06 & 17.06 & 25.06 & 2.07 & 08.07 & 16.07 & 21.07 & 29.07 & 06.08 & 13.08\end{array}$

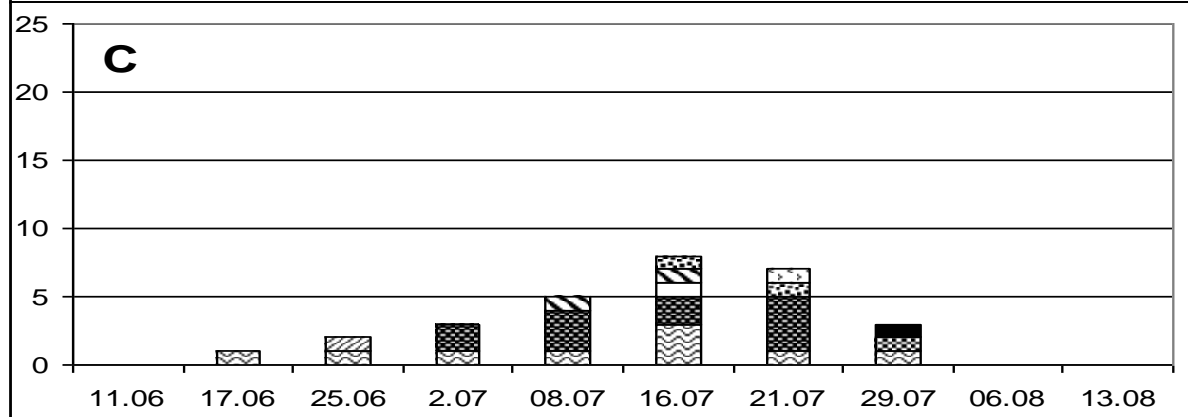

P. xylostella

$\square$ Diadegma semiclausum

圆 Cotesia fuliginosus

Mesochorus spp.

Oomyzus sokolonskii
웅 Diadegma fenestralis

$\Delta$ Diadromus collaris

Cotesia longipalpis

* Habrocytus sp.

A - cabbage in homogenous crop

B - cabbage intercropped with French Marigold (Tagetes patula nana)

C - cabbage intercropped with Pot Marigold (Calendula officinalis)

Fig. 2. Number of parasitoid adults and diamondback moths obtained from the collected cocoons according to the type of cultivation on the example of year 2003 
217 specimens of parasitic wasps belonging to 8 species from families: Ichneumonidae (4 species), Braconidae (2 species), Pteromalidae (1 species) and Eulophidae (1 species) emerged from the collected DBM pupae. Species composition and numbers of parasitoids are presented in Table 3 .

In each year of observations the most abundant species among the Plutella parasitoids was Diadegma fenestralis Holmgr. as it constitued $65 \%$ of all of the reared wasps (Table $3)$. In the 2004 D. fenestralis was the only species (Table 3) parasitizing $88 \%$ (Table 2) of larvae. In Poland, in research of Łagowska (1981) D. fenestralis was the dominant species reducing $40-90 \%$ of pest population. Also observations of the dominant parasitoid species $D$. fenestralis were made by Wiech and Jankowska (1999), Wiech and Kałmuk (2002, 2003), Jankowska and Wiech (2006). This species was introduced from Europe to India where it became a natural enemy of $P$. xylostella (Devi \& Raj 1995; Usha et al. 1997).

Table 2. Effect of rearing pupae of diamondback moth (Plutella xylostella L.) collected from cabbage crops

\begin{tabular}{lccccccccc}
\hline \multirow{2}{*}{$\begin{array}{c}\text { Effect } \\
\text { of rearing }\end{array}$} & \multicolumn{2}{c}{2003} & \multicolumn{2}{c}{2004} & \multicolumn{2}{c}{2005} & \multicolumn{2}{c}{ Total } \\
\cline { 2 - 9 } & $\begin{array}{c}\text { Num- } \\
\text { ber }\end{array}$ & $\%$ & $\begin{array}{c}\text { Num- } \\
\text { ber }\end{array}$ & $\%$ & $\begin{array}{c}\text { Num- } \\
\text { ber }\end{array}$ & $\%$ & $\begin{array}{c}\text { Num- } \\
\text { ber }\end{array}$ & $\%$ \\
\hline Plutella xylostella L. & 79 & 34.8 & 5 & 12 & 14 & 30.5 & 98 & 31 \\
Parasitoids & 148 & 65.2 & 37 & 88 & 32 & 69.5 & 217 & 69 \\
Total & 227 & 100 & 42 & 100 & 46 & 100 & 315 & 100 \\
\hline
\end{tabular}

The other numerous parasitoids of $P$. xylostella caterpillars were: $D i$ adromus collaris Holmgr. and Cotesia longicauda. Both of these species parasitized about $11.5 \%$ of DBM larvae (Table 3). D. collaris has been recorded in many parts of the world as an important parasitoid of the diamondback moth and introduced to Asia (Talekar 1996) and to New Zealand (Beck \& Cameron 1990). In Poland it was reported by Łagowska (1981) and Miczulski (1996). D. collaris was described as larval-pupal (Avci \& Ozbek 1990) or pupal (Okada 1991) parasitoid. Braconids belonging to genus Cotesia are considered as the most important representatives of this family reducing the number of DBM larvae (Lagowska 1981, Rice \& Hahr 1994, Talekar 1996).
Another ichneumonid species emerging from $P$. xylostella larvae were $D$. semiclausum and $C$. fuliginosus (Table 3). Also three species of hyperparasitoids were reared: Mesochorus spp., Habrocytus $s p$. and Oomyzus sokolowskii. The action of the secondary parasitoids limits the efficiency of the primary parasitoids in controlling DBM populations. However, their presence is negligible and has no significant economic impact.

The attractiveness of flowers is an important characteristic that should be taken into account for the selection of flowering plants and tailoring nectar supply to the requirements of parasitoids holds potential to increase their effectiveness as biological control agents (Bianchi \& Wäckers 2008). 
Also Winkler et al. (2006) stress the importance of providing suitable nectar sources as an integral part of biological control programmes. Nawrocka (2006) noted that the number of entomophagous species (parasitoids and predators) were always higher on intercropped cabbage plants. Jankowska (2007) noted that on plots where cabbage was intercropped with Pot Marigold and French Marigold cabbage aphid parasitization by Diaeretiella rapae M'Intosh was greater and the percentages of predatory Syrphidae to prey were more favorable than on homogenous crop. However, studies conducted there were no significantly different between level of parasitization in relation to the cultivation method (Table 4). Also Wiech and Jankowska (1999) found no differences between the level of parasitism of the DBM larvae collected from the cabbage in homogenous crop and those intercropped with white clover.

Table 3. Species composition and quantities of parasitoid emerged from pupae of the diamondback moth (Plutella xylostella $\mathrm{L}$.)

\begin{tabular}{|c|c|c|c|c|c|c|c|c|c|}
\hline \multirow{2}{*}{ Family /Species } & \multicolumn{2}{|c|}{2003} & \multicolumn{2}{|c|}{2004} & \multicolumn{2}{|c|}{2005} & \multicolumn{2}{|c|}{ Total } & \multirow{2}{*}{$\begin{array}{c}\text { Kind of } \\
\text { parasitiza- } \\
\text { tion } \\
\end{array}$} \\
\hline & No. & $\%$ & No. & $\%$ & No. & $\%$ & No. & $\%$ & \\
\hline $\begin{array}{l}\text { Family: Ichneumonidae } \\
\text { Diadeg- } \\
\text { ma semiclausum Hellen }\end{array}$ & 3 & 2 & 0 & 0 & 0 & 0 & 3 & 1.4 & $\begin{array}{l}\text { parasite of } \\
\text { DBM larvae }\end{array}$ \\
\hline $\begin{array}{l}\text { Diadegma fenes- } \\
\text { tralis Holmgr. }\end{array}$ & 84 & 56,8 & 37 & 100 & 20 & 62.5 & 141 & 65 & $\begin{array}{c}\text { parasite of } \\
\text { DBM larvae }\end{array}$ \\
\hline $\begin{array}{l}\text { Diadromus collaris } \\
\text { Holmgr. }\end{array}$ & 18 & 12.2 & 0 & 0 & 7 & 21.9 & 25 & 11.5 & $\begin{array}{l}\text { parasite of } \\
\text { DBM pupae }\end{array}$ \\
\hline Mesochorus spp. & 5 & 3.4 & 0 & 0 & 0 & 0 & 5 & 2.3 & $\begin{array}{l}\text { hyperparasi- } \\
\text { toid }\end{array}$ \\
\hline $\begin{array}{l}\text { Family: Braconidae } \\
\text { Cotesia longicauda } \\
\text { Wesm. }\end{array}$ & 20 & 13.5 & 0 & 0 & 5 & 15.6 & 25 & 11.5 & $\begin{array}{l}\text { parasite of } \\
\text { DBM larvae }\end{array}$ \\
\hline $\begin{array}{l}\text { Cotesia fuliginosus } \\
\text { Wesm. }\end{array}$ & 12 & 8.1 & 0 & 0 & 0 & 0 & 12 & 5.5 & $\begin{array}{c}\text { parasite of } \\
\text { DBM larvae }\end{array}$ \\
\hline $\begin{array}{l}\text { Family: Pteromalidae } \\
\text { Habrocytus sp. }\end{array}$ & 2 & 1.3 & 0 & 0 & 0 & 0 & 2 & 1 & $\begin{array}{c}\text { hyperparasi- } \\
\text { toid }\end{array}$ \\
\hline $\begin{array}{l}\text { Family Eulophidae } \\
\text { Oomyzus sokolowskii } \\
\text { Kurd. }\end{array}$ & 4 & 2.7 & 0 & 0 & 0 & 0 & 4 & 1.8 & $\begin{array}{l}\text { hyperparasi- } \\
\text { toid }\end{array}$ \\
\hline Total & 148 & 100 & 37 & 100 & 32 & 100 & 217 & 100 & \\
\hline
\end{tabular}


Table 4. Comparison of the occurrence of parasitoids of diamondback moth (Plutella xylostella L.) in relation to the cultivation method (2003-2005)

\begin{tabular}{lccc}
\hline \multicolumn{1}{c}{$\begin{array}{c}\text { Species of } \\
\text { parasitoids }\end{array}$} & $\begin{array}{c}\text { Cabbage (ho- } \\
\text { mogenous crop) }\end{array}$ & $\begin{array}{c}\text { Cabbage with } \\
\text { Tagetes patula }\end{array}$ & $\begin{array}{c}\text { Cabbage with } \\
\text { Calendula } \\
\text { officinalis }\end{array}$ \\
\hline Diadegma semiclausum Hellen & $\mathbf{2 0 0 3}$ & & \\
Diadegma fenestralis Holmgr & 1 & 1 & 1 \\
Diadromus collaris Holmgr. & 43 & 30 & 11 \\
Mesochorus spp. & 9 & 7 & 2 \\
Cotesia fuliginosus Wesm. & 2 & 2 & 1 \\
Cotesia longicauda Wesm. & 5 & 5 & 2 \\
Habrocytus sp. & 9 & 10 & 1 \\
Oomyzus sokolowskii Kurd. & 0 & 1 & 1 \\
Total & 1 & 2 & 65 a \\
Parasitization \% & 70 & 58 & 2 \\
& 67 a & 63 a & 100 \\
\hline Diadegma fenestralis Holmgr & $\mathbf{2 0 0 4}$ & & \\
Parasitization \% & 28 & 7 & 1 \\
\hline & 74 & 90 & 1 \\
\hline Diadegma fenestralis Holmgr. & $\mathbf{2 0 0 5}$ & & 2 \\
Diadromus collaris Holmgr. & 17 & 2 & 100 \\
Cotesia longipalpis Reinhard & 6 & 1 & \\
Total & 3 & 4 & \\
Parasitization \% & 26 & 54 & \\
\hline
\end{tabular}

\section{CONCLUSIONS}

1. On plots where cabbage was intercropped the number of DBM larvae and pupae was significantly lower compared with control variant (homogenous crop). The combination with Pot Marigold turned out to be the best in this respect.

2. The parasitization of DBM larvae varied between the years and oscillated from 65 to $88 \%$ and was a very important factor reducing the number of emerging diamondback moths.

3. Eight species belonging to families: Ichneumonidae (4 species), Braconidae (2 species), Pteromalidae (1 species) and Eulophidae
(1 species) emerged from the collected DBM pupae. In each year of observations the most abundant species among Plutella parasitoids was Diadegma fenestralis Holmgr. as it constitued $65 \%$ of all of reared wasps.

4. No differences were determined between the level of parasitization in relation to the cultivation method.

\section{REFERENCES}

Andow D.A. 1991. Vegetational diversity and arthropod population response. Annual Review of Entomology 36: 561-568.

Åsman K., Ekbom B., Rämert B. 2001. Effect of intercropping on oviposition and emigration behavior of the 
leek moth (Lepidoptera: Acrolepiidae) and the Diamondback Moth (Lepidoptera: Plutellidae). Environ. Entomol. 30 (2): 288-294.

Avci U., Ozbek H. 1990. Lepidopterous cabbage pests and their parasitoids in Erzurum. Proc. of the second Turkish National Congress of Biological Control.: 319-330.

Beck N.G., Cameron P.J. 1990. Comparison of lepidopteran pest populations and their parasitoids in three vegetable brassicas. Proceedings of the Forty Thrid New Zeland Weed and Pest Control Conference: 21-25.

Bianchi F., Wäckers F. 2008. Effects of flower attractiveness and nectar availability in field margins on biological control by parasitoids. Biological Control 46 (3): 400-408.

Biever K.D., Hostetter D.L., Kern J.R. 1994. Evolution and implementation of a biological control-IPM system for crucifers: a 24-year case study. American Entomol. 40: 103-108.

Buranday R.P., Raros R.S. 1975. Effect of cabbage-tomato intercropping on the incidence and oviposition of the diamondback moth Plutella $x y$ lostella (L.). Philippines Entomol. 2: 369-374.

Devi N., Raj D. 1995. Biology and parasitization of the diamondback moth, $P$. xylostella L. infesting cauliflower in mid hill region of Himchal Pradesh (India). J. Entomol. Res. 19: 83-86.

Dover J.W. 1986. The effect of labiate herbs and white clover on Plutella xylostella oviposition. Entonol. Exp. Appl. 39: 177-182.

Finch S., Kienegger M. 1997. A behavioural study to help clarify how undersowing with clover effects hostplant selection by pest insects of Brassica crops. Entomol. Exp. Appl. 84: 165-172.

Gupta P.D., Thorsteinson A. J. 1960. Food plant relationships of the diamondback moth (Plutella maculi- pennis (Curt)). Ent. Exp. Appl. 3: 305-314.

Jankowska B. 2005. The comparison of the occurrence of the diamondback moth Plutella xylostella L. (Lepidoptera, Plutellidae) on the different cabbage vegetables. Veget. Crops Res. Bull. 62: 153-163.

Jankowska B. 2006. The occurrence of some Lepidoptera pests on different cabbage vegetables. J. Plant Protection Res. 46 (2): 181-190.

Jankowska B. 2007. Impact of intercropping white cabbage with Pot Marigold (Calendula officinalis L.) and French Marigold (Tagetes patula nana) on the occurrence of cabbage aphid (Brevicoryne brassicae L.), its parasitoid Diaeretiella rapae M'Intosh and predatory Syrphidae. Aphids and Other Hemipterous Insects 13: 199-209.

Jankowska B., Poniedziałek M., Jędrszczyk E. 2009. Effect of intercropping white cabbage with French Marigold (Tagetes patula nana) and Pot Marigold (Calendula officinalis L.) on the plants colonization by herbivorous pest insects. Folia Hort. 21(1): 95-103.

Jankowska B., Wiech K. 2006. The composition and role of parasitoids in reducing population densities of diamondback moth Plutella xylostella L. on different cabbage vegetables. J. Plant Protection Res. 46 (3): 275 284.

Łagowska B. 1981. Ichneumonidae $\mathrm{i}$ Braconidae (Hymenoptera) jako pasożyty tantnisia krzyżowiaczka Plutella maculipennis CURT. (Lepidoptera, Plutellidae). Pol. Pismo Entomol. 51: 355-362. [in Polish]

Miczulski B. 1996. Błonkówki (Hymenoptera) w biocenozie upraw rzepaku. Część II. Gąsieniczniki (Ichneumonidae). Pol. Pismo Entomol. 43-44: 264-292. [in Polish]

Mitchell E.R., Hu G.Y., Okine J.S. 1997. Diamondback moth (Lepidoptera: 
Plutellidae) infestation and parasitism by Diadegma insulare (Hymenoptera: Ichneumonidae) in collards and adjacent cabbage fields. Florida Entomologist 80: 1, 54-71.

Nawrocka B. 2006. Wpływ roślin nektarodajnych na entomofaunę występującą na kapuście głowiastej. Prog. Plant Protection / Post. Ochr. Roślin 46(2): 74-80. [in Polish]

Okada T. 1991. Seasonal changes in population density of the diamondback moth, P. xylostella (L.) and parasitism by parasitoids in cabbage fields. Proceedings of the Kansai Plant Protection Society 33: 39-44.

Pawar D.B., Lawande K.E. 1995. Effects of mustard as a trap crop for diamondback moth on cabbage. J. Maharashtra Agricultural Universites 20 (2): 185-186.

Perrin R.M., Philips M.L. 1978. Some effects of mixed cropping on the population dynamics of insects pests. Ent. Exp. Appl. 24: 385-393.

Pivnick K.A., Jarvis B.J., Slater G.P., Gillot C., Underhill E.W. 1999. Attraction of the diamondback moth (Lepidoptera, Plutellidae) to voliaties of oriental mustard: The influence of age, sex and prior exposure to mates and host-plants. Enviromental Entomology 19: 704-709.

Rice S.E., Hahr D.M. 1994. Biological control of insect pests of cabbage and other cruciferous. Practical Approaches to Biological Control. Univ. of Wisconsin: 17-23.

Srinivasan K., Moorthy P.N.K. 1991. Indian mustard as a crop for menagement of major lepidopterous pests on cabbage. Tropical Pest Menagement. $37,1: 26-32$.

Talekar N.S. 1996. Biological control of diamondback moth in Taiwan. Plant Prot. Bull. 38: 167-189.

Talekar N.S., Shelton A.M. 1993. Biology, ecology and management of the diamondback moth. Ann. Rev. Entomol. 38: 275-301.
Theunissen J., Schelling G. 1996. Undersowing crops of white cabbage with strawberry clover and spurrey. IOBC/WPRS Bull. 19: 128-135.

Usha C., Bhalla O.P., Sharma K.C. 1997. Biology and seasonality of the diamondback moth, $P$. xylostella L. (Lepidoptera: Yponomeutidae) and its parasitoids on cabbage and cauliflower. Pest Menag. Hortic. Ecosyst. 3 (1): 7-12.

Wiech K. 1993. Wpływ współrzędnej uprawy późnej kapusty z koniczyną białą i fasolą szparagową na występowanie szkodliwej i pożytecznej entomofauny. Zesz. Probl. AR Kraków, Ser. Rozpr. 177, 74 pp. [in Polish].

Wiech K., Jankowska B. 1999. Preliminary observations on Diadegma fenestralis a parasitoid of the diamond-back moth, Plutella maculipennis. Integrated Control in Field. Vegetable Crops IOBC Bulletin 22 (5): 145-149.

Wiech K., Kałmuk J., 2002. The role of parasitoids in decreasing the number of diamond back moth (Plutella $x y$ lostella L.) in horticultural crops. The BCPC Conference: 1: 329-334.

Wiech K., Kałmuk J. 2003. Observations on the composition and effectiveness of diamondback moth (Plutella xylostella L.) parasitoids. IOBC/WPRS Bull. 26: 141-147.

Wiech K., Kałmuk J. 2005. Uprawy współrzędne sposobem na zmniejszenie zużycia pestycydów. In: Ochrona środowiska naturalnego w XXI wieku, nowe wyzwania i zagrożenia. Fundacja na rzecz wspierania badań naukowych. W.O., AR w Krakowie: 126-136. [in Polish]

Wiech K., Wnuk A. 1991. [The effect of intercropping cabbage with white clover and french bean on the occurrence of some pests and beneficial insects.] Folia Hort. 3: 39-25. [in Polish with English summary] 
Winkler K., Wäckers F., BukovinszkineKiss G., Lenteren van J. 2006. Sugar resources are vital for Diadegma semiclausum fecundity under field conditions. Basic and Applied Ecology. 7 (2): 133-140.

\section{WPŁYW WSPÓŁRZĘDNEJ UPRAWY KAPUSTY BIAŁEJ Z NAGIETKIEM KARŁOWYM (CALENDULA OFFICINALIS L.) I AKSAMITKĄ NISKĄ PEŁNĄ (TAGETES PATULA NANA) NA WYSTĘPOWANIE TANTNISIA KRZYŻOWIACZKA PLUTELLA XYLOSTELLA L. I JEGO PARAZYTOIDÓW}

Streszczenie

W latach 2003-2005 badano wpływ współrzędnej uprawy kapusty białej z nagietkiem karłowym (Calendula officinalis L.) 'Promyk' i aksamitką niską pełną (Tagetes patula nana) 'Kolombina' na występowanie tantnisia krzyżowiaczka Plutella xylostella L. oraz związanych z nim parazytoidów. Na poletkach, gdzie kapusta była uprawiana współrzędnie, stwierdzono istotnie mniej gąsienic i poczwarek tantnisia. Najlepsza pod tym względem okazała się kombinacja z nagietkiem. Spasożytowanie wahało się w poszczególnych latach od 65 do $85 \%$. Nie stwierdzono istotnych różnic w spasożytowaniu w zależności od sposobu uprawy. Z zebranych poczwarek wyhodowano 8 gatunków parazytoidów z rodzin Ichneumonidae (4 gatunki), Braconidae (2 gatunki), Pteromalidae (1 gatunek) i Eulophidae (1 gatunek). We wszystkich latach gatunkiem dominującym był Diadegma fenestralis Holmgr. 